\section{Journal policy on research funded by the tobacco industry}

\author{
Fiona Godlee, Ruth Malone, Adam Timmis, Catherine Otto, \\ Andrew Bush, lan Pavord, Trish Groves
}

As editors of the BMJ, Heart, Thorax and BMJ Open, we have decided that the journals will no longer consider for publication any study that is partly or wholly funded by the tobacco industry. Our new policy is consistent with those of other journals including PLOS Medicine, PLoS One, PLoS Biology; ${ }^{1}$ Journal of Health Psychology; ${ }^{2}$ journals published by the American Thoracic Society; ${ }^{3}$ and the BMJ's own Tobacco Control. ${ }^{4}$

Critics may argue-as many did when journals stopped publishing cigarette advertisements-that publishing such research does not constitute endorsing its findings and that, as long as funding sources are fully disclosed, readers can consider that information and make up their own minds about the quality of the work. Peer review should prevail, goes this line of thinking: it's not the editor's job to make these kinds of judgments. However, this view ignores the growing body of evidence that biases and research misconduct are often impossible to detect, ${ }^{5}$ and that the source of funding can influence the outcomes of studies in invisible ways. $^{6} 7$

Underlying all the activity of peer review, editing and publishing is the assumption that medical journals exist for the purpose of advancing knowledge that can be used to promote health and reduce disease. But the deputy editor of JAMA, Drummond Rennie, who has perhaps studied the process of scientific publishing longer than anyone, has written about what he calls 'little murders.' These are deceptive publication practices that are 'destructive of the delicate web of trust between colleagues that keeps the whole enterprise functioning and afloat." 8 The editor's job, observes Rennie, is to 'try to separate the insufferable behaviors of mere jerks from the illegal actions of bona fide crooks.'

The tobacco industry, far from advancing knowledge, has used research to deliberately produce ignorance and to

\section{BMJ, London, UK}

Correspondence to Dr Trish Groves, BMJ, BMA House, Tavistock Square, London WC1H 9JR, UK; tgroves@bmj.com advance its ultimate goal of selling its deadly products while shoring up its damaged legitimacy. ${ }^{9}$ We now know, from extensive research drawing on the tobacco industry's own internal documents, that for decades the industry sought to create scientific and popular ignorance or 'doubt.' At first, this doubt related to the fact that smoking caused lung cancer; later, it related to the harmful effects of secondhand smoke on non-smokers, and the true effects of using so-called light or reduced tar cigarettes on smokers' health. ${ }^{9-12}$ Journals unwittingly played a role in producing and sustaining this ignorance. 9

Some who work within public health and who buy the notion of 'harm reduction' argue that the companies that now produce modified cigarette products and non-cigarette tobacco products, including electronic nicotine delivery devices (e-cigarettes), are different from the tobacco industry of old, or that the tobacco industry has changed. For 'hardened' cigarette smokers who can't or won't quit cigarettes, ${ }^{13}$ the argument goes, new tobacco products could represent potential public health gains, and company-sponsored research may be the first to identify those gains.

But one fact remains unassailably true: the same few multinational tobacco companies continue to dominate the market globally and, as smaller companies develop promising products, they are quickly acquired by the larger ones. However promising any other products might be, tobacco companies are still in the business of marketing cigarettes. As US federal court judge Gladys Kessler pointed out in her judgment in the case of US Department of Justice versus Philip Morris et al, the egregious behaviour of these companies is continuing and is likely to continue into the future. ${ }^{14}$ And just this summer, documents leaked from one company showed a concerted campaign to 'ensure that PP [plain packaging of tobacco products, bearing health warnings but only minimal branding] is not adopted in the UK.' ${ }^{15}$ The tobacco industry has not changed in any fundamental way, and the cigarette-the single most deadly consumer product ever made- remains widely available and aggressively marketed.

Editors of $B M J$ journals are committed to integrity in scientific publishing and to ensuring that-as far as possible-their journals publish honest work that advances knowledge about health and disease. Back in 2003, the editor of the $B M J$ defended publication of a study with tobacco industry funding saying 'The BMJ is passionately antitobacco, but we are also passionately prodebate and proscience. A ban would be antiscience. ${ }^{16}$ But it is time to cease supporting the now discredited notion that tobacco industry-funded research is just like any other research. Refusing to publish research funded by the tobacco industry affirms our fundamental commitment not to allow our journals to be used in the service of an industry that continues to perpetuate the most deadly disease epidemic of our times.

This article is being copublished as an editorial in the BMJ, Heart and Thorax, and as a blog in BMJ Open.

Competing interests None.

Provenance and peer review Not commissioned; not externally peer reviewed.

To cite Godlee F, Malone R, Timmis A, et al. Heart 2014; 100:2-3.

Accepted 13 September 2013

Published Online First 16 October 2013

Heart 2014;100:2-3.

doi:10.1136/heartjnl-2013-204531

\section{REFERENCES}

1 PLoS Editors. A new policy on tobacco papers. PLoS Med 2010;7:e1000237.

2 Marks DF. A higher principle is at stake than simply freedom of speech. BMJ 1996;312:773-4.

3 Caplan AL. Should our journals publish research sponsored by the tobacco industry? Con: the smoking lamp should not be lit in ATS/ALA publications. Am J Respir Crit Care Med 1995;12:125-6.

4 Malone RE. Changing Tobacco Control's policy on industry-funded research. Tob Control 2013;22:1-2.

5 Bero LA, Glantz S, Hong MK. The limits of competing interest disclosures. Tob Control 2005;14:118-26.

6 Bero LA, Glantz SA, Rennie D. Publication bias and public health policy on environmental tobacco smoke. JAMA 1994;272:133-6.

7 Barnes DE, Bero LA. Why review articles on the health effects of passive smoking reach different conclusions. JAMA 1998;279:1566-70.

8 Rennie D. Integrity in scientific publishing. Health Serv Res 2010;45:885-96.

9 Proctor RN. Agnotology in action. In: Proctor RN, ed. Golden holocaust: origins of the cigarette catastrophe and the case for abolition. University of California Press, 2011:289-304.

10 Glantz S, Slade J, Bero L, et al. The cigarette papers. University of California Press, 1996.

11 Proctor RN. The history of the discovery of the cigarette-lung cancer link: evidentiary traditions, corporate denial, global toll. Tob Control 2012;21:87-91. 
12 Brandt AM. The cigarette century: the rise, fall, and deadly persistence of the product that defined America. Basic Books, 2007.

13 Cohen JE, McDonald PW, Selby P. Softening up on the hardening hypothesis. Tob Control 2012;21:265-6.
14 United States District Court for the District of Columbia. Amended Final Opinion, US Department of Justice versus Philip Morris et al. Civil action no 99-2496 (GK). 2006. http://publichealthlawcenter. org/sites/default/files/resources/doj-finalopinion.pdf
15 Doward J. Revealed: tobacco giant's secret plans to see off plain cigarette packets. Guardian 2013. http://www.theguardian.com/business/2013/ju//28/ philip-morris-plain-packaging

16 Smith R. Passive smoking: comment from the editor. BMJ 2003;327:505.2. 